\title{
STUDI FENOMENOLOGI TENTANG MAKNA HIDUP PADA PEREMPUAN PELAKU ABORTUS PROVOCATUS CRIMINALIS DALAM FASE REMAJA DI KOTA SURABAYA
}

\author{
Sri Dewi Indah Lestari ${ }^{1}$ \\ Agustina Engry ${ }^{2}$
}

Fakultas Psikologi Universitas Katolik Widya Mandala Surabaya

\begin{abstract}
ABSTRAK
Remaja sebagai pelaku abortus provocatus criminalis memiliki dampak baik fisik maupun psikologis, dikarenakan keputusan yang diambil untuk menjalani abortus sangatlah dilematis, kontroversial, dan beresiko. Bahkan seringkali perempuan yang melakukan abortus provocatus criminalis merasa malu, takut, sedih, stresss, merasa berdosa, ingin bunuh diri dan lain sebagainya. Oleh karena itu, sangat dimungkinkan kondisi psikologis seorang remaja yang melakukan abortus provocatus criminalis bersifat dinamis dalam artian pergerakan dari kondisi psikologis pre-aborsi, ketika melakukan aborsi, dan pasca aborsi. Pergerakan kondisi psikologis tersebut, memunculkan konsep kebermaknaan hidup yang bersumber dari nilai-nilai kreatif (creative values), nilai-nilai penghayatan (experiential values), dan nilai-nilai bersikap (attitudional values). Penelitian ini menggunakan metode kualitatif dengan model fenomenologi Teknik yang digunakan adalah wawancara dengan analisis koding dan kategorisasi model inductive, yang melibatkan dua orang informan yang bertindak sebagai pelaku abortus provocatus criminalis pada saat usia remaja. Validitas penelitian yang dilakukan adalah validitas komunikatif, dan argumentatif. Penelitian ini menemukan bahwa makna hidup wanita pelaku abortus provocatus criminalis pada saat usia remaja bersumber dari nilai-nilai yang memunculkan suatu harapan bagi individu dan pedoman dalam menjalankan kehidupannya sehari-hari. Faktor resiko seperti ajakan dari teman-teman untuk kembali ke dalam dunia pergaulan bebas membuat informan berdinamika, meskipun dirinya sudah berjanji untuk tidak kembali ke dalam dunia tersebut. Sedangkan faktor protektif seperti komitmen, keluarga baru, dan refleksi atas pengalaman masa lalu memberikan penguat dalam mempertahankan harapan-harapan yang berperan sebagai tujuan hidup.
\end{abstract}

Kata kunci : Abortus Provocatus Criminalis, Creative Values, Experiental Values, Attitudional Values, Makna Hidup,

\begin{abstract}
Teenagers as perpetrators of abortion provocatus criminalis have both physical and psychological effects, because decisions taken to undergo abortion is very dilemma, controversial, and risky. In fact, often women who carry out abortion provocatus criminalist they feel embarrassed, afraid, sad, stresssed, feel guilty,
\end{abstract}


want to commit suicide and so on. Therefore, it is very possible the psychological condition of a teenager who has performs abortion provocatus criminalist, is dynamic in terms of movement from the psychological condition of pre-abortion, when to execute an abortion, and post-abortion. The movement of these psychological conditions raises the concept of meaningful life that comes from creative values, experiential values, and attitudinal values. This study uses qualitative methods with phenomenology models. The technique used was an interview with an inductive model coding and categorization analysis, which involved two informants who acted as perpetrators of criminalist provocatus abortion in their teenagers. The validity of the research conducted was communicative validity and argumentative validity. This study found that the meaning of life of women perpetrators of abusive provocatus criminalis at the age of adolescence originated from creative values, experiental values and attitudional values. These values give rise to an expectation for individuals who are used as guidelines in carrying out their daily lives. On the other, also raises risk factors such as the invitation from friends to return to the world of free association made the informants dynamically, even though her self promised not to return to the bad world. Whereas factors protective such as commitment, new family and reflection on past experiences provide reinforcement to defend expectations that act as life goals.

Keyword : Abortus Provocatus Criminalis, Creative Values, Experiental Values, Attitudional Values, Meaning of Life,.

\section{PENDAHULUAN}

Perilaku pacaran khususnya remaja saat ini mengarah pada bentuk perilaku pacaran yang negatif. Seharusnya perilaku tersebut dilakukan dalam suatu ikatan perkawinan yang disepakati secara hukum dan normatif oleh kedua belah pihak. Namun hal tersebut telah mengalami pergeseran, dimana sebagian remaja masa kini menganggap bahwa hubungan seks pada masa pacaran adalah hal biasa dan wajar (Triany, 2007). Salah satu dampak pacaran negatif adalah kehamilan yang tidak diinginkan (KTD). Pada remaja, kehamilan tidak diinginkan (KTD) terjadi karena remaja belum memiliki kesiapan untuk menjalani kehamilan, baik secara psikis, sosial, fisik, ataupun secara ekonomi. Remaja yang mengalami kehamilan tidak diinginkan (KTD) banyak diantaranya yang tidak mendapat dukungan lingkungan sosialnya, remaja dikucilkan, dapat menurunkan prestasinya atau bahkan terpaksa berhenti sekolah. Secara psikis tentu akan ada tekanan, baik itu perasaan bersalah, menyesal, ataupun malu (Siyoto, 2017: 4). Tekanan-tekanan tersebut baik secara sadar maupun tidak sadar telah terinternalisasi dan memberikan nuansa dilematis pada kondisi psikologis remaja. Yang artinya, dari proses tersebut munculah sebuah keputusan yang mereka nilai sebagai satusatunya jalan untuk keluar dari masalah yang dialami. Remaja melakukan abortus provocatus criminalis dengan upaya mengkoreksi dampak kehamilan tidak diinginkan (KTD) atas perilaku seks yang mereka lakukan. Keputusan tersebut dipengaruhi banyak hal seperti pengalaman dalam lingkup unit sosial, bias dalam hal menganggap dirinya akan aman dari resiko, tekanan sosial, kurangnya kontrol 
emosi dan situasi pada saat itu (Beth, dkk, dalam Diclemente, Santeli \& Crosby, 2009).

Dalam kajian hukum sangatlah jelas mengatakan bahwa adanya dampak psikologis bagi sang pelaku abortus provocatus criminalis, apa lagi jika kondisi kehamilan tersebut dialami oleh seorang remaja. Dampak psikologis yang terjadi disebabkan oleh keputusan yang diambil untuk menjalani abortus bukanlah sebuah keputusan yang mudah, namun sangatlah dilematis, kontroversial, dan beresiko, seperti: pengumpulan bekuan darah, infeksi, robekan pada mulut rahim, perforasi (luka tembus) pada dinding peranakan, missed abortion atau kegagalan dalam pengakhiran kehamilan, pendarahan, kemandulan dan juga ganguan psikologis pasca abortion syndrome (PAS). Seringkali perempuan yang melakukan abortus provocatus criminalis merasa malu, takut, sedih, stresss, merasa berdosa, ingin bunuh diri dan lain sebagainya.

Berdasarkan hasil penelitian David dan Lee (dalam Matlin, 2004) sebagian besar perempuan menyatakan bahwa mereka dapat mengatasi reaksi psikologis primer yang terjadi akibat abortus yang mereka alami. Memang beberapa wanita mengalami rasa sedih, kehilangan, berdosa ataupun perasaan-perasaan negatif lainnya. Hal tersebut juga tidak dapat dipungkiri bahwa perbedaan individual terhadap reaksi emosi dalam menghadapi abortus ini sangatlah luas. Bagaimanapun juga penelitian menunjukan bahwa beberapa wanita yang mengalami abortus ternyata tidak lama mengalami dampak psikologis dari abortus itu seperti kecemasan ataupun masalah harga diri. Hal ini menunjukan bahwa ternyata perempuan yang mengalami abortus ini dapat beradaptasi dengan baik dan menemukan makna hidup dibalik peristiwa yang mereka alami (Algeier \& Algeier dalam Matlin, 2004).

Menurut Frankl (dalam Bastaman, 2007: 45) makna hidup adalah segala hal yang dianggap sangt penting maupun berharga serta memberikan nilai khusus bagi seseorang, sehingga layak untuk dijadikan tujuan dalam kehidupan (the purpose of life). Apabila hal itu berhasil dipenuhi makan akan membuat seseorang merasakan kehidupan yang berarti dan juga menimbulkan perasaan bahagia (happiness). Makna hidup juga dapat ditemukan dalam kehidupan itu sendiri, meskipun buruknya kehidupan tersebut. Makna hidup tidak saja dapat ditemukan dalam keadaan-keadaan yang menyenangkan, tetapi juga dapat ditemukan dalam penderitaan sekalipun, selama kita mampu melihat hikmah-hikmahnya. Frankl (dalam Bastaman, 2007) menyebutkan bahwa hidup bisa dibuat bermakna melalui ketiga jalan. Ketiga jalan itu ialah: (1) melalui apa yang kita berikan kepada hidup (creative values), (2) melalui apa yang kita ambil dari hidup (experiential values), dan (3) melalui sikap yang kita berikan terhadap ketentuan atau nasib yang bisa kita ubah (attitudional values). Sangat dimungkinkan kondisi psikologis seorang remaja yang melakukan abortus provocatus criminalis bersifat dinamis dalam artian pergerakan dari kondisi psikologis pre-aborsi, ketika melakukan aborsi, dan pasca aborsi. Pergerakan kondisi psikologis dalam konteks abortus provocatus criminalis yang dilakukan oleh remaja, memunculkan konsep kebermaknaan hidup dimana kenakalan remaja menjadi latar belakangnya. Apabila hal ini diteliti lebih lanjut, akan ditemukan variabel internal maupun eksternal yang mempengaruhi munculnya konsep kebermaknaan hidup pada remaja yang 
melakukan abortus provocatus criminalis. Hal ini akan menjelaskan secara mendalam bagaimana hubungan sebab akibat yang terjadi sebagai hasil pengambilan keputusan individu dengan dampak psikologis maupun penghayatan nilai-nilai yang ada.

Pada artikel jurnal pertama terkait dengan abortus di atas, merupakan deskripsi dari perilaku pacaran pada mahasiswa yang mengalami kehamilan tidak diinginkan dari sisi kesehatan. Pembahasan artikel jurnal yang kedua merupakan deiskripsi dampak-dampak seorang wanita yang mengalami abortus spontaneous dari sisi psikologis. Di samping itu, dalam artikel jurnal penelitian lainnya mengkaji kebermaknaan hidup pada anak jalanan perempuan yang memiliki anak atas kehamilan yang tidak dikehendaki. Selama ini penelitian yang dilakukan terkait dengan perilaku abortus banyak dilakukan dalam bidang hukum, kesehatan dan psikologi dalam konteks abortus spontaneous. Berbeda dengan penelitian lainnya dalam penelitian ini, peneliti mencoba mendeskripsikan perilaku abortus dalam ranah psikologi dan lebih spesifik lagi pada kasus abortus provocatus criminalis sebagai dampak dari kenakalan remaja di Surabaya. Ranah psikologi yang peneliti maksud ialah deskripsi makna hidup pada perempuan pelaku abortus provocatus criminalis dalam fenomena perilaku abortus provocatus criminalis pada remaja. Deskripsi tersebut muncul pada pemikiran, perasaan, dan perilaku informan pasca melakukan abortus provocatus criminalis, serta bagaimana individu dapat menghayati nilai-nilai makna hidupnya dalam setting kesehariannya serta intraksi dengan faktor-faktor baik secara internal maupun eksternal.

Berdasarkan penjelasan di atas, peneliti tertarik untuk mengetahui pemaknaan hidup pada perempuan pelaku abortus provocatus criminalis setelah melakukan aborsi pada fase usia remaja, karena pada saat itu mereka diharuskan berhadapan dengan pengambilan keputusan yang tidak sesuai dengan tugas-tugas perkembangannya. Pentingnya penelitian ini berfokus pada proses pengambilan keputusan remaja yang melakukan abortus provocatus criminalis, dimana mereka dalam kasus ini dihadapkan dengan konsekuensi-kosekuensi logis serta dituntut untuk lebih bertanggung jawab terhadap setiap perilaku yang dipilihnya.

\section{METODE PENELITIAN}

Pendekatan yang digunakan dalam penelitian ini adalah kualitatif, namun secara spesifik penelitian ini diarahkan kepada pendekatan fenomenologi. Collin (dalam Sukidin, 2002) menyatakan bagaimana manusia berfikir tentang dirinya sendiri melalui pembicaraan dan bagaimana mereka berfikir tentang pembicaraan mereka berdasarkan pengetahuan yang mereka miliki. Poerwandari (1998: 36) menambahkan, bahwa penelitian kualitatif berfokus pada penyelidikan yang mendalam pada sejumlah kasus kecil yang telah dipilih sesuai minat dan tujuan khusus yang diuraikan dalam tujuan penelitian. Penelitian kualitatif ini secara spesifik lebih diarahkan pada studi fenomenologi.

Selain itu peneliti juga melakukan teknik analisis data dalam penelitian ini adalah inductive thematic analysis. Inductive thematic analysis adalah suatu proses penarikan tema yang muncul dan menjadi jelas karena adanya data-data 
pendukung (Hayes, 2000: 176-178). Adapun proses pelaksanaan dalam menganalisis data untuk inductive thematic analysis adalah sebagai berikut:

a. Menyiapkan data untuk analisis, transkrip wawancara ataupun catatan.

b. Membaca hasil wawancara secara mendetail, teliti, memberikan tanda pada kata-kata yang merupakan inti dari pertanyaan informan (potongan keci) yang relevan dengan topik penelitian. Proses inipun wajib dilakukan secara terpisah pada setiap hasil transkrip.

c. Menyatukan dan mengkelompokkan potongan bagian kecil yang relevan dari setiap hasil transkrip kedalam tema. Pada tahap ketiga ini juga peneliti dapat melakukan proses pentemaan, artinya dengan topik penelitian dapat ditempatkan dalam suatu kelompok yang sudah dibagi.

d. Memeriksa hasil pentemaan dan menjadikan definisi sebagai kata kunci.

e. Mengambil setiap tema secara terpisah dan diujikan kembali setiap hasil transkrip secara teliti untuk materi yang relevan pada tema tersebut.

f. Menyusun bentuk akhir dari pentemaan yang memiliki tiga bagian, yaitu: nama, lebel untuk suatu tema, analisa tema, dan data pendukung (hasil transkirp dalam proses wawancara)

g. Memilih dan menentukan data yang relevan melalui data tersebut dapat menjelaskan hasil laporan dari pentemaan

Pengumpulan data akan dilakukan dengan teknik wawancara mendalam (depth interview) dengan dua orang informan yakni informan D (21) dan R (22). Pada informan D (21) proses pengambilan data dilakukan secara tiga tahap, tahap pertama dilakukan pada 02 Desember 2018, tahap kedua pada 15 Februari dan tahap ketiga pada 08 Maret 2019. Informan $\mathrm{R}$ (22) proses pengambilan data dilakukan secara tiga tahap, tahap pertama 21 November 2018, tahap kedua 27 Januari 2019 dan 10 maret 2019. Peneliti tidak menggunakan significant other, hal tersebut dikarenakan fenomena yang diangkat dalam penelitian ini yakni pelaku abortus provocatus criminalis, memiliki sensifitas dalam ranah ruang lingkup personal. Oleh karena itu, peneliti memutuskan untuk melakukan wawancara pada pelaku abortus provocatus criminalis secara personal tanpa melibatkan pihak lain yang dalam hal ini ialah keluarga ataupun teman-teman terdekat. Dalam penelitian kualitatif, temuan atau data dapat dinyatakan valid apabila tidak ada perbedaan antara yang dilaporkan peneliti dengan apa yang sesungguhnya terjadi pada objek yang diteliti (Sugiyono, 2009: 268-269). Oleh karena itu, pada penelitian ini peneliti melakukan validitas komunikatif dan validitas argumentative. Berjalannya validitas tersebut dapat dikonfirmasi dengan tahapan-tahapan pengolahan data yang peneliti lakukan bersama professional judgement, yaitu: memastikan informan penelitian untuk mengkonfirmasi hasil penelitian, memastikan ulang presentasi temuan dan kesimpulan dapat diikuti dengan baik rasional. 


\section{HASIL PENELITIAN DAN DISKUSI}

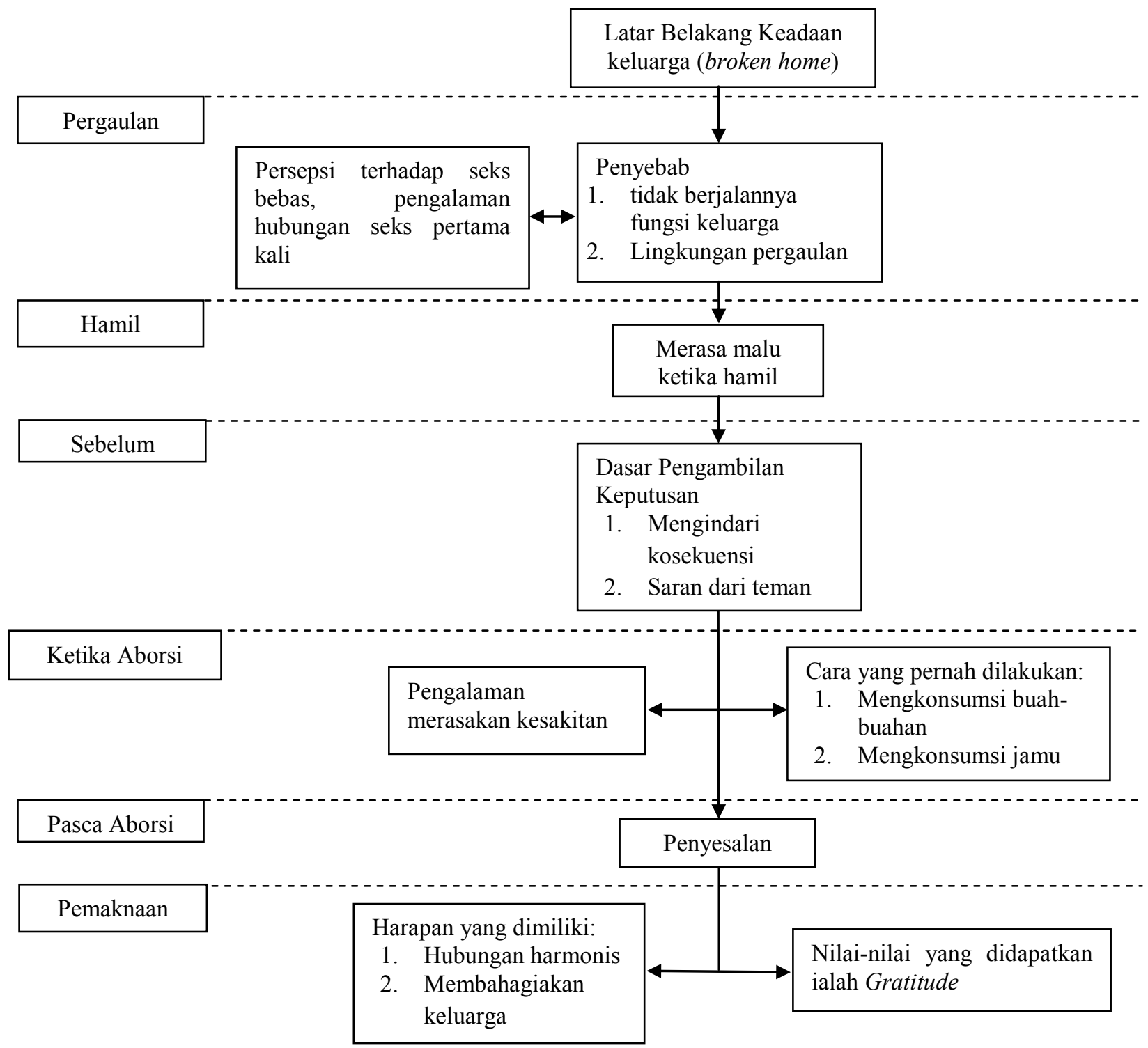


Sri Dewi Indah Lestari, Agustina Engry : Studi fenomenologi tentang makna hidup pada...

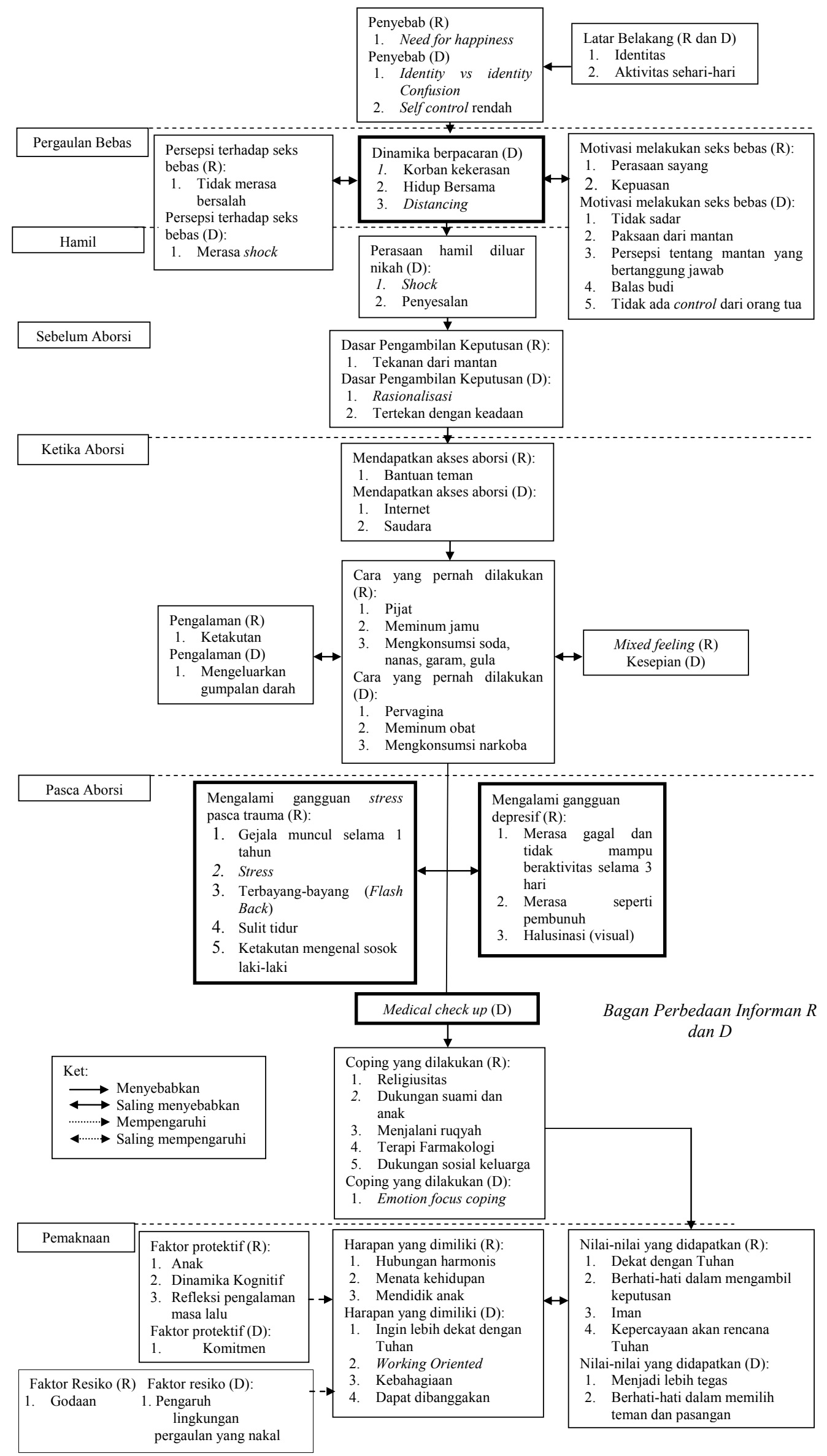


Makna hidup adalah suatu hal yang dianggap penting bagi individu, berharga, dan adanya nilai khusus dalam menjalani kehidupan sehingga hal tersebut dapat dijadikan sebagain tujuan dalam kehidupan. Jika makna hidup berhasil dipenuhi maka akan membuat individu merasakan kehidupan yang lebih berarti dan mampu menimbulkan perasaan yang bahagia (happiness). Pandangan terhadap makna hidup pada setiap individu berbeda antara individu yang satu dan yang lainnya, karena makna hidup bersifat personal, spesifik, tetap dan universal. Makna hidup juga tidak selalu bersifat hal dunia, ada yang dapat memaknai kehidupannya dengan nilai-nilai keagaaman, padangan filsafat dan ideologiideologi tertentu yang dimana dianggap memiliki nilai atau values yang dijadikan sebagai tujuan dalam mencapai makna hidup. Hal tersebut juga sejalan dengan pendapat Frankl (dalam Bastaman, 2007) bahwa makna hidup bisa ditemukan dalam berbagai keadaan apapun dalam rentan kehidupan yang dimiliki oleh manusia. Makna kehidupan itu sendiri bisa saja terjadi saat dalam keadaan bahagia dan menyenangkan maupun dalam keadaan sulit bagi manusia. Begitu juga pada perempuan yang memilih melakukan abortus provocatus criminalis pada fase remaja di kota Surabaya, mereka juga menemukan makna kehidupannya seteleh mengalami masa-masa sulit dalam rentan kehidupan yang mereka alami saat usia remaja.

Ketika proses pengambilan data ditahap awal penelitian, kedua informan D dan $\mathrm{R}$ memiliki latar belakang keluarga yang berfondasikan dari keluarga broken home. Keadaan keluarga yang broken home membuat kedua informan kehilangan sosok yang menjadi panutan bagi mereka. Keadaan keluarga yang dingin dan tidak bersahabat, membuat individu dalam usia remaja rentan terjerumus dalam perilaku menyimpang. Keadaan keluarga broken home membuat tidak berjalannya fungsi utama dari keluarga dalam diri individu. Menurut Hurlock (dalam Retnowati, dkk 2003: 94) salah satu fungsi keluarga adalah sosialisasi nilai keluarga mengenai bagaimana anak bersikap dan berperilaku. Keluarga adalah lembaga yang pertama kali mengajarkan individu bagaimana individu mengeksplorasi emosinya. Keluarga dapat memberikan fondasi primer bagi perkembangan anak, sedangkan lingkungan sekitar dan sekolah ikut memberikan nuansa pada perkembangan anak. Ketika keluarga dan lingkungan sekitar kurang mendukung adanya fondasi tersebut, delikuensi pada remaja dapat muncul dan menjadi akar permasalahan dalam kepribadian seorang anak. Selain itu, ketidakberadaan fungsi keluarga juga menjadikan hilangnya individu dari batasbatas moral yang ada. Seharusnya pendidikan batas-batas moral tersebut dapat dipelajari dalam nasehat-nasehat orang tua, namun dalam keadaan individu yang berada dalam keluarga broken home hal tersebut tidak diperoleh dan akhirnya mereka menganut nilai-nilai moral dalam lingkungan pergaulannya (peer group).

Kelompok bermain atau peer group merupakan unit sosial terkecil kedua setelah keluarga dimana memberikan sumbangsih atasberkembangnya perilaku remaja. Selain itu, kelompok bermain atau peer group menjadi sebuah media untuk memperluas jejaring pergaulan interaksi sosial remaja. Menurut Soerjono Soekanto (1987:51), interaksi sosial merupakan kunci semua kehidupan sosial. Di dalam kehidupan sehari-hari tentunya manusia tidak dapat lepas dari hubungan antara satu dengan yang lainnya, ia akan selalu perlu untuk mencari individu 
ataupun kelompok lain untuk dapat berinteraksi ataupun bertukar pikiran. Begitupun juga dengan apa yang terjadi pada diri individu yang menginjak usia remaja. Remaja yang sering berinterakasi dengan teman-temannya sangat merasakan kehadiran kelompoknya, sehingga tingkah laku kelompoknya akan sangat berarti bagi dirinya. Selain itu remaja tidak terlalu membatasi tingkah laku dengan aturan norma yang ada di masyarakat pada umumnya. Mereka kurang mempertimbangkan konsekuensinya, tetapi mereka akan tunduk pada aturan yang ada pada kelompoknya.

Pada informan D menyatakan bahwa penyebab dirinya terjerumus dalam dunia kenaklalkan remaja dikarenakan kurangnya perhatian dari keluarga (tidak berjalananya fungsi keluarga) membuat informan terjerumus dalam kenakalan remaja, selain itu adanya lingkungan perguaulan dari mantan pacar informan yang mempengaruhi informan untuk melakukan berbagai macam bentuk kenalakan remaja saat itu menyebabkan informan tidak meimiliki kendali untuk menolak pengaruh buruk yang berkembang dalam lingkungan pergualannya (self control yang rendah). Ketidak berdayaan yang dialami informan tersebut secara tidak langsung juga dialami oleh informan $\mathrm{R}$, dimana dirinya menyatakan bahwa penyebab informan $\mathrm{R}$ terjerumus ke dalam kenakalan remaja dikarenakan untuk mendapatkan kebahagiaan. Kebahagiaan informan $\mathrm{R}$ pada saat itu didapatkan dari mantan pacar informan serta adanya lingkungan yang mendukung.

Dari kedua pernyataan informan tersebut dapat ditarik kesimpulan bahwasanya jiwa remaja berada dalam keadaan yang tidak seimbang (disequilibrium) dimana hal tersebut dipicu oleh masalah utama dari remaja yaitu kekacauan identitas (identity confused). Kekacauan identitas mencapai puncaknya pada tahap remaja. Pada fase ini individu sibuk dengan diri sendiri, dilatarbelakangi oleh masa pubertas genital yang memberi berbagai peluang konflik, baik yang berhubungan dengan seks, pekerjaan, keyakinan diri dan filsafat hidup. Remaja akan selalu mencoba-coba peran baru sambil terus berusaha menemukan identitas ego yang mantap (Alwisol, 2004). Selain itu, penyesuaian diri dengan standar kelompok dianggap jauh lebih penting bagi remaja dari pada individualitas. Apabila tidak demikian ia akan terusir dari kelompok bermainnya (peer group), dan sebagai kompensasinya individu tersebut akan merasa kesepian dan ditolak oleh lingkungan sosialnya. Ketidakinginan untuk ditolak dalam lingkungan sosial itulah yang menyebabkan seorang remaja merasakan perasaan bebas dan bahagia jikalau mereka melakukan sesuatu sesuai dengan tanpa ada aturan yang mengikat.

Menurut Berliana (2014: 10) perilaku seksual pranikah sebagai bentuk pergaulan bebas dapat menyebabkan berbagai kerugian diantaranya adalah terjadi kehamilan yang tidak diinginkan, aborsi tidak aman, penularan penyakit menular seksual termasuk HIV/AIDS, dan gangguan psikososial. Hal tersebut sejalan dengan apa yang dialami oleh informan $\mathrm{D}$ dan $\mathrm{R}$ bahwasanya mereka sama-sama mengalami kehamilan di luar nikah setelah telah lama melakukan perilaku seks bebas bersama dengan pasangannya.Informan $\mathrm{R}$ mengaku bahwa penyebab dirinya mau untuk melakukan hubungan seks dengan pasangannya ialah karena timbul perasaan sayang yang mendalam dan untuk memperoleh kepuasan. Hal tersebut sejalan dengan Maharani \& Wulanyani (2018: 231) yang menegaskan 
bahwa salah satu alasan remaja putri melakukan seks pranikah adalah sebuah bukti rasa cinta dan sangat mencintai pacar, rasa ingin tahu, terbujuk oleh rayuan pacar, merasa sudah dewasa dan merasa sudah pantas untuk melakukan hubungan seks pranikah. Sedangkan, kepuasan yang dimaksud oleh informan $\mathrm{R}$ ialah dirinya tidak keberatan dan merasa senang ketika melakukan hubungan seks dengan pasangannya. Hal itu dapat dibuktikan dengan perilaku informan $\mathrm{R}$ yang tidak pernah menolak ajakan pasangannya untuk melakukan hubungan seks. Stenberg (dalam Premaswari \& Lestari, 2017: 313) menjelaskan bahwa perasaan sayang seperti apa yang dialami oleh informan $\mathrm{R}$ tergolong dalam komponen cinta passion atau cinta romantis, dikarenakan perasaan cinta tersebut di dominasi oleh ketertarikan fisik dan pemenuhan kebutuhan seksual dengan pasangan. Dalam hubungan cinta romantis, ketertarikan fisik dan seksual mungkin adalah yang utama, namun motif lainnya seperti kebutuhan akan harga diri, kebutuhan akan afiliasi dan kebutuhan untuk mendominasi juga bekontribusi dalam passion. Passion merupakan unsur motivasional yang menyebabkan individu merasa ingin dekat secara fisik, menikmati atau merasakan sentuhan fisik, bahkan melakukan hubungan seksual dengan pasangannya. Hal tersebut juga selaras dengan apa yang dirasakan oleh informan $\mathrm{R}$ bahwa dirinya merasa takut ditinggal pasangannya, dan akhirnya menuruti permintaan pasangannya untuk melakukan aborsi.

Sebaliknya, hal-hal yang membuat informan D mau melakukan hubungan seks pranikah dengan pasangannya adalah ketidaksadaran, paksaan yang menimbulakan kekerasan fisik dan verbal, penilaian terhadap mantan yang bertanggung jawab, serta memunculkan pemikiran balas budi. Berbeda dengan apa yang dialami oleh informan $\mathrm{R}$, motivasi informan $\mathrm{D}$ untuk mau melakukan hubungan seks pranikah lebih ke dalam sesuatu yang bersifat eksternal. Teori pembelajaran sosial Albert Bandura (dalam Putri, dkk, 2017:1098), menyatakan bahwa kepribadian seseorang berkembang melalui proses pengamatan, dimana orang belajar melalui observasi atau pengamatan terhadap perilaku orang lain terutama pemimpin atau orang yang dianggap mempunyai nilai lebih dari orang lainnya. Perilaku acuan yang menjadi role model dari informan $\mathrm{D}$ dalam hal ini ialah pasangannya. Pasangan D meninggalkan kesan sebagai orang yang bertanggung jawab, sehingga informan D tanpa sadar terikat dalam sebuah dinamika yang berujung dalam proses penanaman moral values. Segala hal yang dilakukan oleh pasangan informan $\mathrm{D}$ meskipun hal tersebut adalah hal yang buruk, akan selalu dinilai sebagai sesuatu yang baik karena ada norma sosial dalam kelompoknya (mengajak untuk hidup tinggal bersama). Hal tersebutlah yang menjelaskan mengapa informan $\mathrm{D}$ merasa seperti harus balas budi dan tidak bisa menolak keinginan dari pasangannya meskipun dirinya telah mengalami perlakuan kasar baik secara fisik dan verbal.

Pada informan $\mathrm{D}$ dan $\mathrm{R}$ memiliki dasar pengambilan keputusan untuk melakukan aborsi. Informan $\mathrm{D}$ pengambil keputusan untuk melakukan aborsi karena saat usia remaja yaitu mengindari konsekuensi, pemikiran berdosa jika tidak melakukan aborsi dan semakin berdosa jika tidak mampu membesarkan anak dengan baik (rasionalisasi), dan mendapatkan tekanan keadaan yang pada saat itu informan sendiri tidak mampu mendapatkan kebutuhan hidup sehingga mendapatkan dukungan financial dari teman dan saudara (keluarga om). Berbeda 
dari informan $\mathrm{D}$, informan $\mathrm{R}$ mengambil keputusan untuk aborsi saat itu karena tekanan dari mantan yang menyuruh informan $\mathrm{R}$ untuk melakukan aborsi, sehigga pada saat itu informan mau melakukan aborsi karena adanya perasaan sayang yang berlebihan terhadap mantan pacar yang menyebabkan informan $\mathrm{R}$ mau untuk melakukan aborsi.

Apa yang dialami oleh informan $\mathrm{D}$ maupun informan $\mathrm{R}$ adalah pengalaman untuk melakukan aborsi dalam rangka melenyapkan janin sebagai akibat hubungan seksual di luar perkawinan (abortus provocatus criminalis). Pada penelitian ini hasil yang didapatkan bahwa proses aborsi yang dilakukan oleh kedua informan sangatlah berbeda satu sama lain meskipun mereka pernah samasama mengkonsumsi buah-buah masam yang dipercaya dapat menggugurkan kandungan seperti nanas. Ketika melakukan abortus provocatus criminalis Informan D memilih untuk membeli obat pengugur melalui internet (online), sedangkan informan $\mathrm{R}$ memilih untuk datang ke dukun pijat. Semua metode yang dipilih informan memiliki keunikan masing-masing dalam proses penggunaanya. Informan $\mathrm{D}$ yang memilih melakukan aborsi dengan menggunakan obat penggugur yang didapatkan melalui trasaksi elektronik, mengkonsumsi obat yang diperolehnya dengan cara memasukan obat pengugur tersebut ke dalam rahim melalui vagina (pervagina). Efek dari obat tersebut ialah rasa sakit yang teramat sangat pada bagian perut, lalu di ikuti dengan pendaharahan hebat selama satu malam dan diakhiri dengan keluarnya gumpalan darah serta janin. Sedangkan informan $\mathrm{R}$ yang didampingi oleh temannya, melakukan aborsi dengan cara pijat sehingga pada saat itu informan $\mathrm{R}$ melihat secara langsung bagaimana proses ketika mengeluarkan gumpalan darah disertakan janin yang keluar dari rahim informan. Setelah melakukan aborsi kedua informan mengalami dampak psikologis yang sama. Hal tersebut dikarenakan keputusan yang diambil oleh perempuan untuk menjalani aborsi bukanlah keputusan yang mudah. Sehingga secara mental, kedua informan yang memilih melakukan aborsi, sedang mengalami kegalauan, rasa tidak percaya diri, kekhawatiran yang berlebihan, putus asa, penyesalan, perasaan bersalah dan berdosa yang disebut dengan dengan ganguan pasca abortion syndrom (PAS) (Wijayanti, 2015: 51). Hal tersebut terlihat pada gejala-gejala (PPDGJ) yang dialami oleh informan R seperti mengalami stresss, selalu terbayang-bayang (flashback) peristiwa dimana ia melakukan aborsi, sulit tidur, ketakutan mengenal sosok laki-laki dan gejala-gejala tersebut informan alami selama 1 tahun. Atas pengamalan yang menyakit itu memunculkan efek traumatis dan dampak psikologis yang dialami oleh informan R. Pada saat itu informan R menceritakan bahwa adanya dukungan sosial yang didapatkan dari keluarga untuk menjalanin perawatan farmakologi di salah satu rumah sakit jiwa Surabaya serta melakukan proses ruqyah. Ruqyah adalah suatu terapi penyembuhan dari penyakit fisik maupun psikis dengan ayat-ayat AlQur'an, asma Allah dan doa-doa. Ruqyah dalam bahasa Arab jika diartikan dalam bahasa Indonesia berarti jampi atau mantera. Jampi-jampi atau mantera sudah lama diamalkan oleh manusia sebelum kedatangan Islam dan ia mengandung katakata yang tidak dimengerti, atau memuja dan menyeru pertolongan kepada selain Allah sebagai sarana bagi penyembuhan suatu penyakit yang sedang diderita (dalam Akhmad, 2005: 87-96). 
Pada informan $\mathrm{R}$ dukungan sosial dari keluarga sangat mempengaruhi bagaimana ia bisa bangkit dari masa lalunya. Hal tersebut menandakan bahwa dukungan sosial berhubungan dengan sejauhmana individu melakukan interaksi atau transaksi interpersonal dalam lingkungannya, semakin individu memiliki sekelompok orang yang kuat dan suportif, semakin luas dan mendalam jaringan sosial maka kemungkinan untuk mengembangkan gangguan stresss pasca trauma akan jauh lebih kecil (Caroll dkk dalam Durand \& Barlow, 2006). Dalam penelitian "Dukungan Sosial dan Post Traumatic Stress Disorder pada Remaja Penyintas Gunung Merapi" oleh Tentama (2014: 133-138) menjelaskan bahwa ada hubungan negatif yang signifikan antara dukungan sosial dengan gangguan stresss pasca trauma (PTSD) pada siswa-siswi SMP Negeri 1 Turi Sleman Yogyakarta. Semakin tinggi dukungan sosial yang diterima remaja, maka semakin rendah gangguan stress pasca trauma yangdialami; dan sebaliknya, semakin rendah dukungan sosial yang diterima remaja, maka semakin tinggi gangguan stresss pasca trauma yang dialami.

Berbeda apa yang dialami informan $\mathrm{R}$ tidak sama pada informan $\mathrm{D}$, informan D memusatkan pemikirannya melalui emotion focus coping dengan cara mensugesti diri dengan pemikiran "boleh menyesali hal-hal yang sudah berlalu namun haruslah bangkit lagi." Menurut Lazarus, coping merupakan cara-cara individu dalam menghadapi situasi yang menekan. Cara mengatasi masalah setiap individu bergantung pula pada cara pandang atau penilaian terhadap masalah yang dihadapi. Jika individu dapat menggunakan coping dengan baik maka individu dapat melakukan penyesuaian sosial dengan baik pula. Emotion focus coping sendiri ialah usaha-usaha untuk mengurangi emosi negatif yang muncul sebagai respon terhadap situasi mengancam dengan cara mengubah interpretasi dari situasi yang mengancam tersebut (dalam Gibson, Pessin, McLain, Shah, \& Breitbart, 2004).

Atas pengalaman masa lalu yang dialami oleh kedua informan $\mathrm{D}$ dan $\mathrm{R}$ merupakan sebuah pembelajaran yang memiliki makna tersendiri bagi kehidupan mereka. Menurut Frankl (dalam Bastaman, 2007: 45) makna hidup adalah segala hal yang dianggap sangat penting maupun berharga serta memberikan nilai khusus bagi seseorang, sehingga layak untuk dijadikan tujuan dalam kehidupan (the purpose of life). Makna hidup juga dapat ditemukan dalam kehidupan itu sendiri, meskipun buruknya kehidupan tersebut. Makna hidup tidak saja dapat ditemukan dalam keadaan-keadaan yang menyenangkan, tetapi juga dapat ditemukan dalam penderitaan sekalipun, selama seseorang mampu melihat hikmah-hikmah. Menurut Bastaman (2007), jika individu tidak berhasil menemukan dan memenuhi makna hidupnya, maka biasanya menimbulkan semacam frustasi eksistensial, dimana inividu merasa tidak mampu lagi dalam mengatasi masalah-masalah personalnya secara efisien, merasa hampa, tidak bersemangat dan tidak lagi memiliki tujuan hidup. Mengingat keunikan dan kekhususannya itu, makna hidup tidak dapat diberikan oleh siapa pun, melainkan harus dicari, diselami dan ditemukan sendiri. Negara Di negara Indonesia sendiri aborsi merupakan fenomena yang dipandang tabu dan sensitif. Pandangan demikian ini kemudian melahirkan suatu interpretasi, bahwa para pelaku aborsi akan selalu diikuti secara integral oleh stigma-stigma negatif lainnya, seperti pembunuh, wanita 'nakal' dan 
orang yang tidak memiliki masa depan. Hal tersebutlah yang harus dihadapi oleh informan sebagai pelaku aborsi, dalam menemukan makna hidup yang nantinya dapat digunakan untuk sebagai tujuan dalam kehidupan mereka.

Berdasarkan uriain di atas dapat disimpulkan informan sebagai pelaku abortus provocatus criminalis memiliki pengalaman yang kelam, dimana sebelum melakukan aborsi informan terpengaruh dalam keadaan kenakalan remaja yang sebenarnya merupakan pelarian atas kebutuhan akan kasih sayang keluarga. Mereka tidak meminta untuk di tempatkan ke dalam dunia yang kelam, namun keadaanlah yang membuat diri mereka hanyut. Pada akhirnya mereka harus dihadapkan dengan sebuah keadaan yang menyangkut nilai moral agar mereka dapat terbebas dari jerat dunia pergaulan bebas. Keterpurukan atas pengalaman masa lalu memberikan bekas luka yang mendalam dan memberi makna pada setiap lembar-lembar kehidupannya, yang berfungsi sebagai tujuan hidup, dimana setiap individu memiliki makna dan tujuan hidup yang berbedabeda. Frankl (dalam Bastaman, 2007) menyebutkan bahwa hidup bisa dibuat bermakna melalui ketiga jalan. Ketiga jalan itu ialah: (1) melalui apa yang kita berikan kepada hidup (creative values), (2) melalui apa yang kita ambil dari hidup (experiential values), dan (3) melalui sikap yang kita berikan terhadap ketentuan atau nasib yang bisa kita ubah (attitudional values).

Informan setelah melakukan aborsi, baik informan R dan D menemukan atau mendalami makna hidupnya ketika berada dalam ruang lingkup keluarga barunya dan rutinitas sehari-harinya. Makna hidup yang ditemukan dan didalami oleh informan $\mathrm{R}$ dan $\mathrm{D}$ tersebut, bersumber dari nilai-nilai kreatif (creative values), nilai-nilai penghayatan (experiential values), dan nilai-nilai bersikap (attitudional values). Baik informan $\mathrm{D}$ dan $\mathrm{R}$ menemukan nilai-nilai kreatif (creative values) melalui pekerjaannya. Pekerjaan menurut infrorman $\mathrm{D}$ dan $\mathrm{R}$ sekarang adalah hal yang sangat berarti dan penting sehingga mereka hanya berfokus pada perkerjaannya, bertanggung jawab atas pekerjaan tersebut. Dalam makna hidup melalui creative value, pekerjaan hanyalah sarana yang memberikan kesempatan untuk indvidu dalam menemukan dan mengembangkan makna hidup. Makna hidup sebenarnya tidak terletak pada jenis pekerjaan apapun, tetapi dalam makna hidup lebih mengarahkan pribadi yang bersangkutan. Melalui sikap positif dan mencintai pekerjaannya serta bagaimana cara bekerja yang mampu mencerminkan kualitas pribadi itu.

Penemuan makna hidup kedua pada informan $\mathrm{D}$ dan $\mathrm{R}$ adalah mengenai melalui apa yang kita ambil dari hidup (experiential values). Informan D menemukan experiential values atas sikap penyelasan dan refleksi masa lalu. Penyesalan yang dialami oleh informan $\mathrm{D}$ memunculkan nilai-nilai pengahayatan, kebenaran serta adanya cinta kasih terhadap diri sendiri untuk mencari seorang yang lebih baik dan cinta kasih terhadap orang tua terutama pada Ibu. Cinta kasih tersebut juga berkaitan dengan komitmen informan untuk tidak meneteskan air mata ibunya serta mampu membahagiakan ibu. Sedangkan pada informan R menemukan experiential values melalui keluarganya sekarang. Suami dan anak merupakan pendorong untuk informan $\mathrm{R}$ untuk tetap berada di dalam jalan yang benar, selain itu mendapat perhatian yang lebih dari suami juga memunculkan perasaan cinta kasih sayang pada informan R. Dukungan suami 
yang selalu memberikan nasehat membuat informan $\mathrm{R}$ selalu ingat akan Tuhan dan berbuat baik. Saat individu mampu menghayati dan meyakinkan suatu nilai dapat menjadikan manusia lebih berarti dalam kulitas hidupnya. Cinta kasih yang dialami informan $\mathrm{D}$ dan $\mathrm{R}$ dapat dijadikan juga sebagai rasa pengahayatan. Mencinta dan dicintai akan membuat seseroang lebih merasakan hidupnya penuh dengan pengalaman hidup yang membahagiakan.

Penemuan makna hidup ketiga melalui sikap yang kita berikan terhadap ketentuan atau nasib yang bisa kita ubah (attitudional values). Baik informan D dan $\mathrm{R}$ dapat menemukan attitudional values melalui sikap gratidude. Sikap bersyukur baik pada informan $\mathrm{D}$ dan $\mathrm{R}$ bagaimana mereka dapat mengucapkan rasa terima kasih kepada Tuhan atas pengalaman masa lalu mereka. Pengalaman yang sangat menyedihkan sekalipun membuat mereka mampu bangkit dari masa lalu dan selalu beryukur atas pengalaman masa lalu, dan bersyukur untuk sekarang. Informan $\mathrm{R}$ merasa bersyukur atas suami dan anaknya sekarang. Bagi Informan R, hal tersebut merupakan hal terindah untuknya. Informan R bersyukur karena sekarang dirinya bisa menjadi seorang Ibu dan dapat mengetahui bagaimana perjuangan untuk melahirkan serta membesarkan anak hingga mampu menjadi pribadi yang lebih baik dari dirinya yang dulu. Sedangkan informan D bersyukur atas segala yang dialaminya, dalam pekerjaan, relasi dengan ibunya menjadi semakin membaik dan kini dirinya bisa membahagiakan ibunya. Dengan pengalaman tersebut informan $\mathrm{D}$ menjadi lebih tahu bagaimana caranya memilih pergaulan dan menjadi lebih tegas dalam memberikan keputusan yang menyangkut prinsip hidupnya. Pengalaman melakukan aborsi memberikan nilai bersikap bagi informan untuk lebih jeli lagi dalam bertindak, dalam memilih teman dan menerima dengan sikap yang positif terhadap ketentuan atau situasi yang tidak dapat lagi diubahnya.

Rasa syukur yang diapatkan oleh kedua informan berhubungan dengan keyakinan yang mereka hayati, dimana hal tersebut memunculkan harapanharapan dalam mencapai tujuan hidup. Emmons dan Mishra (2012) menjelaskan bahwa konsep syukur pada implementasinya akan mengarahkan kondisi yang positif bagi individu salah satunya terkait dengan proses menikmati hidup. Konteks syukur ini menjadikan individu mampu menikmati hidup yang merupakan hasil kemampuan individu untuk melihat hal-hal positif dari proses kehidupan yang dijalaninya. Individu yang bersyukur, tidak lagi memfokuskan tendensi kebahagiaannya kepada hal-hal yang bersifat materi, namun mereka lebih memfokuskannya terhadap situasi yang membuat dirinya merasakan kebahagian dan kepuasan dalam hidup.

Berdasarkan pengalaman hidup yang diperoleh selama melakukan aborsi, informan menyadari akan makna hidupnya. Makna hidup tersebut muncul melalui harapan-harapan yang menjadi pendorong dan pedoman hidup dalam menjalani hidup yang bermakna. Sejalan dengan itu Bastaman (2007) menjelaskan, hidup yang bermakna adalah kehidupan yang sarat dengan kegiatan, penghayatan, dan pengalaman-pengalaman bermakna, apabila hal itu dipenuhi maka akan menimbulkan perasaan-perasaan bahagia dalam kehidupan seseorang. Tujuan hidup baik tujuan jangka pendek maupun jangka panjang berisikan kegiatan-kegiatan yang dilakukan lebih terarah dan merasakan sendiri kemajuan- 
kemajuan yang telah dicapai. Tugas-tugas dan pekerjaan menjadi sumber kepuasan dan kesenangan tersendiri sehingga dalam mengerjakan lebih bersemangat dan bertanggung jawab. Orang yang menghayati hidup bermakna benar-benar tahu untuk apa mereka hidup dan bagaimana mereka menjalani hidup. Informan R menemukan makna hidupnya melalui kehadiran seorang anak dalam keluarga barunya. Informan juga menciptakan makna hidupnya melalui perannya sebagai orang tua. Informan ingin mendidik anaknya agar nantinya jangan sampai mengalami keterpurukan seperti dirinya. Selain itu, sebagai orang tua informan $\mathrm{R}$ memiliki harapan tentang hubungan yang harmonis dan kebahagiaan bersama dengan keluarga. Sebelumnya keadaan keluarga broken home yang membuat dirinya jatuh ke dalam keterpurukan, menyadarkannya bahwa kebahagiaan itu bukanlah sesuatu yang dicari, namun dibentuk yang berfondasikan pengalaman-pengalaman masa lalu. Hal tersebut juga dialami oleh informan D yang juga memiliki latar belakang keluarga broken home. Harapanharapan supaya dapat menata kehidupan barunya terutama dalam kehidupan sehari-hari dan memiliki hubungan keluarga yang harmonis. Apa yang dialami oleh informan $\mathrm{R}$ juga sejalan dengan penelitian "Kebermaknaan Hidup Anak Jalanan Perempuan yang Memiliki Anak atas Kehamilan yang Tidak Dikehendaki" (Pranungsari dan \& Tentama, 2018: 24-34) yang menyebutkan bahwa kebermaknaan hidup subjek pertama didapatkannya setelah memiliki anak. Subjek menjadi lebih bersemangat dalam hidup karena memiliki harapan untuk dapat melihat anaknya tumbuh dengan baik. Subjek juga merasa hidupnya lebih baik setelah memilki anak, termasuk menjadi pribadi yang lebih dewasa. Subjek kedua bahwa kebermaknaan hidup subjek kedua didapatkannya saat proses persalinan. Perjuangan proses persalinan yang berat dan juga perjuangan dalam mengurus anak membuatnya menyesal karena subjek tidak dapat menjadi anak yang baik. Keinginan informan yang kuat untuk mendidik anaknya agar menjadi pribadi yang baik dan patuh kepada orang tua, membuat informan memiliki prinsip baru dalam menjalani kehidupan selanjutnya.

Makna hidup dan harapan yang informan peroleh sebagai pedoman hidup dalam menjalani kehidupan sehari-hari bersifat dinamis. Hal tersebut dikarenakan di dalam lingkungan individu selalu terdapat faktor-faktor yang memungkinkan memberi pengaruh atas perubahan aspek-aspek perilaku yakni pemikiran, perasaan dan konatif. Selain itu, faktor-faktor juga memiliki peran dan pengaruh bagi informan secara subjektif. Faktor protektif adalah sesuatu yang melindungi informan untuk tetap berpegang teguh dalam memaknai hidupnya, sedangkan faktor resiko adalah faktor yang memberikan dampak negatif dalam proses memaknai hidup. Ada kalanya saat melakukan aktifitas, informan $\mathrm{R}$ memiliki relasi dan peran di dalam suatu golongan tertentu. Sebagai seorang teman, kehadiran dalam aktivitas kelompok pertemanan memang memberikan suatu ikatan tersendiri. Namun, ketika kelompok tersebut tidak lagi memiliki keselarasan dalam tujuan dan cara pandang maka yang terjadi ialah penolakan. Hal itulah yang menjadi faktor resiko dari informan $\mathrm{R}$. Terkadang informan $\mathrm{R}$ dihubungi oleh teman lamanya untuk sekedar berkumpul kembali atau menjalin hubungan kembali. Namun informan tidak lagi berada pada posisi yang sama dengan teman-temannya yang notabene berada dalam lingkungan pergaulan 
bebas. Informan yang telah memiliki pedoman dan cara pandang baru dalam menjalani kehidupannya merasa tidak nyaman dan takut jika nantinya kembali ke dalam lingkungan pergaulan bebas dan terjerumus lagi. Pedoman dan cara pandang yang membuat informan bertahan tersebut, bertindak sebagai faktor protektif dimana Informan $\mathrm{R}$ merasa dilindungi dan dikuatkan kembali akan tujuan hidupnya. Adapun faktor protektif tersebut ialah pemikiran tentang anak (keluarga baru), dan refleksi tentang pengalaman masa lalu. Faktor-faktor tersebut berhubungan langsung dengan nilai-nilai yang menjadi sumber pemaknaan informan. Anak yang merupakan keluarga baru dan refleksi pengalaman masa lalu mengajarkan untuk tidak jatuh ke dalam lubang yang sama memberikan suatu dinamika ketika informan digoda untuk kembali ke dalam dunia pergaulan bebas. Berbeda dengan informan $\mathrm{R}$, pada informan $\mathrm{D}$ tidak ditemukan faktor yang membuat dirinya terpuruk kembali. Hal itu terjadi karena informan D tidak memiliki alasan untuk kembali ke dalam dunia pergaulan bebas. Kekuatan penolakan tersebut berasal dari dalam informan $\mathrm{D}$ sendiri, bahwa dirinya sudah berkomitmen untuk tidak kembali ke dalam dunia pergaulan bebas. Hal tersebut sejalan dengan Bastaman (2007) yang menyatakan bahwa salah satu yang membuat seseorang dapat bertahan dalam menjalani hidup bermakan ialah hasrat untuk bermakana (The Will to Meaning). Hasrat untuk hidup bermakna berkaitan dengan setiap orang menginginkan dirinya menjadi orang yang bermartabat dan berguna bagi dirinya, keluarga, lingkungan kerja, masyarakat sekitar dan berharga dimata Tuhan. Apa yang dialami informan $\mathrm{R}$ dan $\mathrm{D}$ menunjukan bahwa The Will to Meaning menyebabkan mereka bertahan dalam menjalani kehidupan seharihari. Membahagiakan keluarga, dan ingin sukses dalam menjalani hidup menjadi tujuan akhir dalam hidup mereka untuk dapat mencapai kebahagiaan.

\section{KESIMPULAN}

Berdasarkan penemuan-penemuan dan pembahasan yang peneliti lakukan pada penelitian "Makna Hidup Pada Perempuan Pelaku Abortus Provocatus Criminalis pada Fase Remaja di Kota Surabaya", dapat disimpulkan bahwa variabel-variabel psikologis yang melatarbelakangi munculnya makna hidup pada perempuan pelaku abortus provocatus criminalis terjadi karena beberapa hal yaitu: latar belakang keluarga, persepsi terhadap seks bebas, tidak berjalannya fungsi keluarga, lingkungan pergaulan, pengambilan keputusan untuk melakukan aborsi, pengalaman dalam melakukan aborsi, dan penyesalan setelah melakukan aborsi, Namun semuanya itu tidak serta merta muncul secara tiba-tiba, adanya pengaruh dari faktor protektif, faktor resiko menjadikan makna hidup seseorang dapat bergerak secara dinamis dan saling mempengaruhi satu sama lain.

Latar belakang kedua informan yang berasal dari keadaan keluarga broken home menyebabkan tidak berjalannya fungsi keluarga dan menyebabkan informan terjatuh dalam dunia pergaulan bebas. Selain itu, lingkungan pergulan yang memberikan nuansa kebahagiaan, dimana kebahagian tersebut tidak informan temukan dalam lingkungan keluarganya. Ketika terjerumus pergaulan bebas kedua informan mengalami kehamilan yang tidak di inginkan, dan mengambil keputusan untuk melakukan aborsi dalam rangka melenyapkan janin yang dikandungnya. Pengambilan keputusan yang dilakukan oleh kedua informan berdasar pada 
kedua faktor utama, yaitu: menghindari kosekuensi dan mendapatkan saran dari teman.

Ketika melakukan aborsi, kedua informan sama-sama mengkonsumsi makanan-makanan dan jamu yang dipercaya dapat menggugurkan kandungan. Dampak dari proses aborsi yang dilakukan tersebut memberikan rasa sakit yang luar biasa, bahkan salah satu informan mengalami trauma dan depresi setelah dirinya melakukan aborsi. Pengalaman kedua informan ketika melakukan aborsi tersebut memunculkan penyesalan yang berujung pada pemaknaan hidup. Pemaknaan hidup yang dialami informan muncul dalam dimensi values dan harapan, dimana values yang muncul ialah rasa syukur dan harapan yang dimiliki ialah hubungan harmonis dalam keluarga serta ingin membahagiakan keluarga.

\section{SARAN}

Adanya keterbatasan dalam penelitian ini, membuat peneliti mempunyai beberapa saran yang dapat digunakan oleh peneliti selanjutnya dalam melanjutkan penelitian ini, adapun saran-saran tersebut adalah:

a. Bagi Peneliti

Bagi peneliti, minimnya literatur buku dan penelitian terdahulu yang mengkaji mengenai fenomena abortus provocatus criminalis dari segi psikologi menjadi permasalahan yang dihadapi. Hal ini cukup menyulitkan peneliti untuk melakukan pengkajian hasil penelitian dengan penelitian sebelumnya. Selain itu peneliti juga merasa kesulitan ketika melakukan probing kepada informan karena informan tidak terlalu memahami makna pertanyaan dari peneliti. Selain itu, informan menggunakan bahasa campuran jawa dan indonesia, sehingga ketika memasuki proses wawancara peneliti sesekali meminta informan menjelaskan istilah-istilah yang tidak dapat dimengerti ke dalam bahasa Indonesia.

b. Bagi Informan

Bagi informan dalam hal ini ialah perempuan pelaku abortus provocatus criminalis pada fase remaja di kota Surabaya agar dapat berpikir positif dalam memaknai setiap pengalaman yang dialami. Ketika mengambil keputusan untuk melakukan aborsi saat usia remaja banyak kenangan pahit dan manis yang telah dilewati. Sehingga dengan hal tersebut, informan dapat lebih mensyukuri bahwa adanya pengalaman yang buruk dimasalah lalu mempunyai maksud yang baik dibalik peristiwa yang dialami. Selanjutnya, pemikiran tersebut dapat menjadikan kehidupan informan menjadi lebih baik dan menemukan makna hidupnya atas pengalaman masa lalu.

c. Bagi Orang Tua

Bagi orang tua yang memiliki anak pada usia remaja, agar lebih memahami pemikiran dan perkembangannya agar fungsi keluarga dapat berjalan sepenuhnya. Fungsi keluarga yang dimaksud ialah ialah pendidikan moral yang ditanamkan oleh keluarga untuk menjaga anak supaya tidak terjerumus dalam dunia kenakalan remaja.

d. Bagi Penelitian Selanjutnya 
Untuk peneliti selanjutnya yang ingin mengembangkan penelitian ini, perlu memahami dan menguasai teknik wawancara yang baik. Penguasaan teknik-teknik wawancara akan memudahkan dalam proses pengambilan data. Selain itu juga peneliti juga harus menguasai metode penelitian kualitatif yang baik dengan begitu peneliti dapat dimudahkan dalam proses analisa data yang lebih baik. Hal lainnya yang perlu dimiliki adalah penguasaan timeline penggalian data. Hal tersebut dibutuhkan karena untuk proses perjanjian kepada informan agar lebih terarahkan sehingga tidak membutuhkan waktu yang lama untuk proses penggalian data.

e. Bagi orang-orang yang berada di lingkungan pergaulan bebas

Melakukan aborsi adalah suatu tindakan yang ilegal dan juga sangat berbahaya baik secara fisik serta emosional. Oleh karena itu bagi orangorang yang berada pada ruang lingkup pergaulan bebas agar dapat benar-benar bijaksana dalam mengambil keputusan, karena pada nantinya keputusan tersebut tidak hanya berdampak pada masa kini, namun juga berdampak pada masa depan dan dalam ruang lingkup orang lain.

\section{REFERENSI}

Akhmad. (2005). Terapi Ruqyah sebagai Sarana sarana Mengobati mengobati Orang orang yang Tidak tidak Sehat sehat Mentalmental. Yogyakarta: Jurnal Psikologi Islami (e journal), 1(1), Juni (2005): 87-96. Diambil pada tanggal 28 Maret 2019 dari https:// 21-1-55-1-10-20170222//

Alwisol. (2004). Psikologi kKepribadian. Malang: Universitas Muhamadiyah.

Bastaman, H. D. (2007). Logoterapi: Psikologi untuk menemukan makna hidup dan meraih hidup bermakna. Jakarta: PT Raja Grafindo Persada.

Berliana. (2014). Peran Faktor dan Karakteristik Remaja terhadap Perilaku Seksual Pranikah. Fakultas Kesehatan Masyarakat Universitas Airlangga. Jurnal Biometrika dan Kependudukan, Vol. 3, No. 1 Juli 2014: 8-19. Diambil pada tanggal 29 Maret 2019 dari https://journal.unair.ac.id/filerPDF/biometrikfde8cc6696full

Diclemente, Santelli, \& Crosby. (2009). Adolescent Health Understanding and Preventing Risk Behaviors. USA: Jhon Wiley \& Son.

Durand, V. M. \& Barlow, D. H. (2006). Psikologi abnormal. Fourth Edition.Penerjemah: H. P. Soetjipto \& S. M. Soedtjipto. Yogyakarta: Pustaka Pelajar.

Emmons, R. A., \& Mishra, A. (2012). Why gratitude enhances well-being: What we know, what we need to know. In Sheldon, K., Kashdan, T., \& Steger, M.F. (Eds.) Designing the future of positive psychology: Taking stock and moving forward. New York: Oxford University Press.

Gibson, C. A. , Pessin, H., McLain, C. S., Shah, A. D., \& Breitbart, W. (2004). The unmet need: Addressing spirituality and meaning through culturally sensitive communication and intervention. Dalam R. J. Moore, \& D. Spiegel (Eds.), Cancer, culture, and communication (281-319). New York, 
NY: Plenum. Diambil pada tanggal 19 April 2019, dari http://books.google.co.id/books

Maharani \& Wulanyani. (2018). Gambaran Harga Diri pada Remaja Putri yang Melakukan Seks Pranikah. Program Studi Psikologi, Fakultas Kedokteran, Universitas Udayana. Jurnal Psikologi Udayana 2018, Vol.5, No.2, 226232. ISSN: 2354 5607. Diambil pada tanggal 28 Maret 2019 dari https:// 40394-1165-82072-1-10-20180630//

Matlin, M. W. (2004). The Psychology of Women, Sixth Edition. USA: Thompson Wadsworth.

Poerwandari, K. (1998). Pendekatan Kualitatif dalam Penelitian Psikologi. Jakarta: Lembaga Pengembangan Sarana dan Pendidikan Psikologi (LPSP3) Fakultas Psikologi Universitas Indonesia.

Pranungsari, Tentama. (2018). Kebermaknaan Hidup Anak Jalanan Perempuan yang Memiliki Anak Atas Kehamilan yang Tidak Dikehendaki. Jurnal Humanitas, Vol.15, No.1, Februari 2018, Hal. 24 - 34 ISSN 1693-7236, Terakreditasi B oleh DIKTI, No: 36a/E/KPT/2016. Diambil pada tanggal 28 September 2018 dari http;//www. 5203-23143-1-PB.ac.id/

Premaswari \& Lestari. (2017). Peran Komponen Cinta pada Sikap Terhadap Hubungan Seksual Pranikah Remaja Akhir yang Berpacaran di Kabupaten Bangli. Program Studi Psikologi, Fakultas Kedokteran, Universitas Udayana. Jurnal Psikologi Udayana 2017, Vol.4, No.2, 305-319. ISSN: 2354 5607. Diambil pada tanggal 28 Maret 2019 dari https:// 37130-116573806-1-10-20180128//

Putri, S.haluhiyah, \& Prabamurti. (2017). Faktor-faktor yang berhubungan dengan Perilaku Seksual Remaja yang Tinggal di Lingkungan Resosialisasi Argorejo Kota Semarang. Bagian Pendidikan Kesehatan dan Ilmu Perilaku, Fakultas Kesehatan Masyarakat Universitas Diponegoro. Jurnal Kesehatan Masyarakat (e-Journal): Volume 5, Nomor 5, Oktober 2017 (ISSN: 2356-3346). Diambil pada tanggal 28 Maret 2019 dari http://ejournal3.undip.ac.id/index.php/jkm

Renowati, Widhiarso, Rohmani. (2003). Peranan Keberfungsian Keluarga pada Pemahaman dan Pengungkapan Emosi. Universitas Gadjah Mada. Jurnal Psikologi: No. 2, 91-104 ISSN: 0215-8884. Diambil pada tanggal 30 Maret 2019 dari https://jurnal.ugm.ac.id/jpsi/article/view/7028.

Siyoto, Sandu. (2017). Analisis Perilaku Pacaran pada Mahasiswa yang Mengalami Kehamilan Tidak Diinginkan Di Kediri. E-Journal: Volume 7 Nomor 1 Agustus 2016 - Januari 2017 ISSN : 1978 - 8940. Diambil pada tanggal 7 September 2018 dari http://www.19-26-1-PB.ac.id/

Soekanto, Soerjono. (1987). Sosiologi Hukum dan Masyarakat. Rajawali: Jakarta.

Sugiyono. (2009). Metode Penelitian Kuantitatif Kualitatif dan $R \& D$. Bandung: CV. Alfabeta.

Taufik, R.acmah \&, Triany. (2007). Seksualitas Remaja : Perbedaan Seksualitas antara Remaja yang Tidak Melakukan Hubungan Seksual dan Remaja yang Melakukan Hubungan Seksual. Jurnal Penelitian Humaniora, Vol. 6, No. 2, 2007: 115-129. Diambil pada tanggal 7 September 2018 dari eprints.ums.ac.id/1206/1/1. TAUFIK.pdf 
Wijayanti, Mufliha. (2015). Aborsi Akibat Kehamilan yang Tak Diinginkan (KTD): Kontestasi Antara Pro-live dan Pro-Choice. ANALISIS: Jurnal Studi Keislaman, Volume 15, Nomor 1, Juni 2015. Diambil pada tanggal 7 September 2018 dari http;//www. 57114-ID-aborsi-akibat-kehamilan yang-tak-diinginkan-2015/ 